\title{
Appropriate uses of EICAT protocol, data and classifications
}

\author{
Sabrina Kumschick ${ }^{1,2}$, Sven Bacher ${ }^{3}$, Sandro Bertolino ${ }^{4}$, \\ Tim M. Blackburn ${ }^{5,6}$, Thomas Evans ${ }^{7}$, Helen E. Roy ${ }^{8}$, Kevin Smith ${ }^{9}$
}

I Centre for Invasion Biology, Department of Botany and Zoology, Stellenbosch University, Matieland, 7602, South Africa 2 South African National Biodiversity Institute, Kirstenbosch Research Centre, Cape Town, South Africa 3 Department of Biology, University of Fribourg, Switzerland 4 Department of Life Sciences and Systems Biology, University of Turin, Torino, Italy 5 Centre for Biodiversity and Environment Research, Department of Genetics, Evolution and Environment, University College London, London, UK 6 Institute of Zoology, Zoological Society of London, London, UK 7 Institute of Biology, Freie Universität Berlin, Königin-Luise-Str. 1-3, 14195, Berlin, Germany 8 UK Centre for Ecology \& Hydrology, Benson Lane, Wallingford, OX10 8BB, UK 9 IUCN (International Union for Conservation of Nature), The David Attenborough Building, Pembroke St, Cambridge, CB2 3QZ, UK

Corresponding author: Sabrina Kumschick (sabrina.kumschick@gmail.com)

Academic editor: J. L. Lockwood | Received 28 February 2020 | Accepted 9 June 2020 | Published 15 October 2020

Citation: Kumschick S, Bacher S, Bertolino S, Blackburn TM, Evans T, Roy HE, Smith K (2020) Appropriate uses of EICAT protocol, data and classifications. In: Wilson JR, Bacher S, Daehler CC, Groom QJ, Kumschick S, Lockwood JL, Robinson TB, Zengeya TA, Richardson DM (Eds) Frameworks used in Invasion Science. NeoBiota 62: 193-212. https:// doi.org/10.3897/neobiota.62.51574

\begin{abstract}
The Environmental Impact Classification for Alien Taxa (EICAT) can be used to classify alien taxa according to the magnitude and type of their environmental impacts. The EICAT protocol, classifications of alien taxa using the protocol (EICAT classification) and the data underpinning classifications (EICAT data) are increasingly used by scientists and practitioners such as governments, NGOs and civil society for a variety of purposes. However, the properties of the EICAT protocol and the data it generates are not suitable for certain uses. Therefore, we present guidelines designed to clarify and facilitate the appropriate use of EICAT to tackle a broad range of conservation issues related to biological invasions, as well as to guide research and communication more generally. Here we address common misconceptions and give a brief overview of some key issues that all EICAT users need to be aware of to take maximal advantage of this resource. Furthermore, we give examples of the wide variety of ways in which the EICAT protocol, classifications and data can be and have been utilised and outline common errors and pitfalls to avoid.
\end{abstract}

Copyright Sabrina Kumschick et al. This is an open access article distributed under the terms of the Creative Commons Attribution License (CC BY 4.0), which permits unrestricted use, distribution, and reproduction in any medium, provided the original author and source are credited. 


\section{Keywords}

Biological invasions, Environmental Impact Classification for Alien Taxa, management, policy-making, prioritisation

\section{Introduction}

A range of scoring schemes have been developed to enable the assessment and comparison of diverse impacts caused by biological invasions among taxa, sites and mechanisms (e.g. Blackburn et al. 2014; Nentwig et al. 2016; Bacher et al. 2018). Such comparisons are needed for a variety of applications, for example, to prioritise management actions to minimise the impacts of alien species (e.g. Kumschick et al. 2016; Nentwig et al. 2018), to study patterns of impacts across regions and taxa (e.g. Evans et al. 2014; Nkuna et al. 2018) and to underpin predictions regarding the types of species that have potentially damaging impacts currently or in the future (Evans et al. 2018). To this end and at the invitation of Parties to the Convention on Biological Diversity (CBD 2014), the Environmental Impact Classification for Alien Taxa (EICAT) has been developed to compare the severity and type of environmental impacts of alien taxa in a simple, transparent and evidence-based manner (Blackburn et al. 2014; Hawkins et al. 2015). EICAT assesses the severity of the impact caused by an alien taxon through its effects on individuals or populations of native species. EICAT has been well received by the invasion biology community [as evidenced by a high number of citations: Blackburn et al. 2014 is considered a highly-cited paper, i.e. within the top $1 \%$ in terms of citations for its age and field (Wilson et al. 2020)], as well as by policymakers (e.g. CBD 2018; Wilson et al. 2018) and has been adopted as an official Standard by the International Union for the Conservation of Nature (IUCN; IUCN 2020a, b).

Given its function as a standard classification scheme for alien taxa and its potential widespread application, there is a need to ensure that current and future users of EICAT are aware of its appropriate application and the ways in which it should, and should not, be used. Here, we first briefly summarise how EICAT works, including how it is applied and its outputs and also clarify the terminology used in this study. Guidelines for applying EICAT have been described comprehensively (IUCN 2020a, b) and we, therefore, mainly refer to relevant documents here and add some points not previously explicitly addressed in detail. Second, we focus on the use and misuse of EICAT. To this end, we provide a table with examples of applications, including descriptions of appropriate and inappropriate uses of EICAT. These guidelines will hopefully encourage and facilitate the use of EICAT for purposes such as management, conservation, research and communication with stakeholders on biological invasions.

Note that this document does not address inconsistencies in the application of EICAT itself, which could lead to ambiguous outcomes and ultimately, data that are difficult to interpret (Kumschick et al. 2017; Gonzalez-Moreno et al. 2019). These issues should be addressed through the full and proper application of the EICAT protocol as documented by the EICAT Categories and Criteria and the Guidelines for application of EICAT Categories and Criteria (see IUCN 2020a, b; Volery et al. 2020). 


\section{Application of EICAT}

The EICAT process relies on published evidence of impacts of the alien taxa under assessment; what counts as evidence in this case has been described elsewhere (e.g. Hawkins et al. 2015; Evans et al. 2016; IUCN 2020a, b; Volery et al. 2020). To summarise, the first step is a thorough and exhaustive literature search to identify all published (including grey) literature on the impacts of an alien taxon. Then, the EICAT protocol is applied to organise all this information in the standardised EICAT format and to classify each impact record for an alien taxon using the EICAT Categories and Criteria and the Guidelines (see also IUCN 2020a, b). The result is a compilation of all impact records available for a certain alien taxon, including the mechanisms of impact, the magnitudes of impact associated with those mechanisms, an EICAT assessment confidence score of 'Low', 'Medium' or 'High' for each record and additional information, such as where the impact took place and which native species were impacted (for details, see

Box I. The EICAT categories.

EICAT classifies taxa into eight categories based on: whether they have been assessed using EICAT; their alien status; impact data availability; and impact magnitude (IUCN 2020a, b). The EICAT categories are:

Not Evaluated (NE): Taxa which have not been assessed using the EICAT protocol.

No Alien Populations (NA): Taxa which have not been introduced to areas outside of their native range.

Data Deficient (DD): Alien taxa which have been assessed using the EICAT protocol, but for which no data were available to classify them.

Minimal Concern (MC): Alien taxa which have been assessed using the EICAT protocol and that do not affect the performance of native taxa (i.e. their impacts to native taxa are negligible).

Minor (MN): Alien taxa which affect the performance of native taxa, but for which there is no evidence to suggest that they lead to decreased population sizes of any native taxon.

Moderate (MO): Alien taxa which have been shown to adversely affect native taxa population size, but which have not caused the local disappearance of any native taxon.

Major (MR): Alien taxa which have caused the reversible local population extinction of at least one native taxon.

Massive (MV): Alien taxa which have caused the irreversible local population extinction of at least one native taxon.

MC, MN, MO, MR and MV are the EICAT impact categories. The three highest magnitudes (MO, MR and $\mathbf{M V}$ ) are termed "harmful" under EICAT. 
Box 2. Terminology.

The three fundamentals of an EICAT assessment are: 1) the protocol used to perform EICAT assessments (EICAT protocol), 2) the data collected and assessed using the EICAT protocol (EICAT data) and 3) the resulting classification of an alien taxon using the data collected with the EICAT protocol (EICAT classification) (Fig. 1).

EICAT protocol: The protocol used to classify alien taxa according to the magnitude of their environmental impacts on native species, as described in detail in the Categories and Criteria and Guidelines documents (see also IUCN 2020a, b; Volery et al. 2020).

EICAT data: The evidence collected during EICAT assessments and provided as supporting information for EICAT classifications, including all records of impact for the taxon under assessment and their categories and criteria. The type of data and the standardised process in which it is collected is governed by the EICAT protocol.

EICAT classification: The classification of any alien taxon (mostly species) according to the EICAT Categories and Criteria and Guidelines (IUCN 2020a, b), i.e. the maximum impact recorded for the taxon and associated mechanism and confidence score.

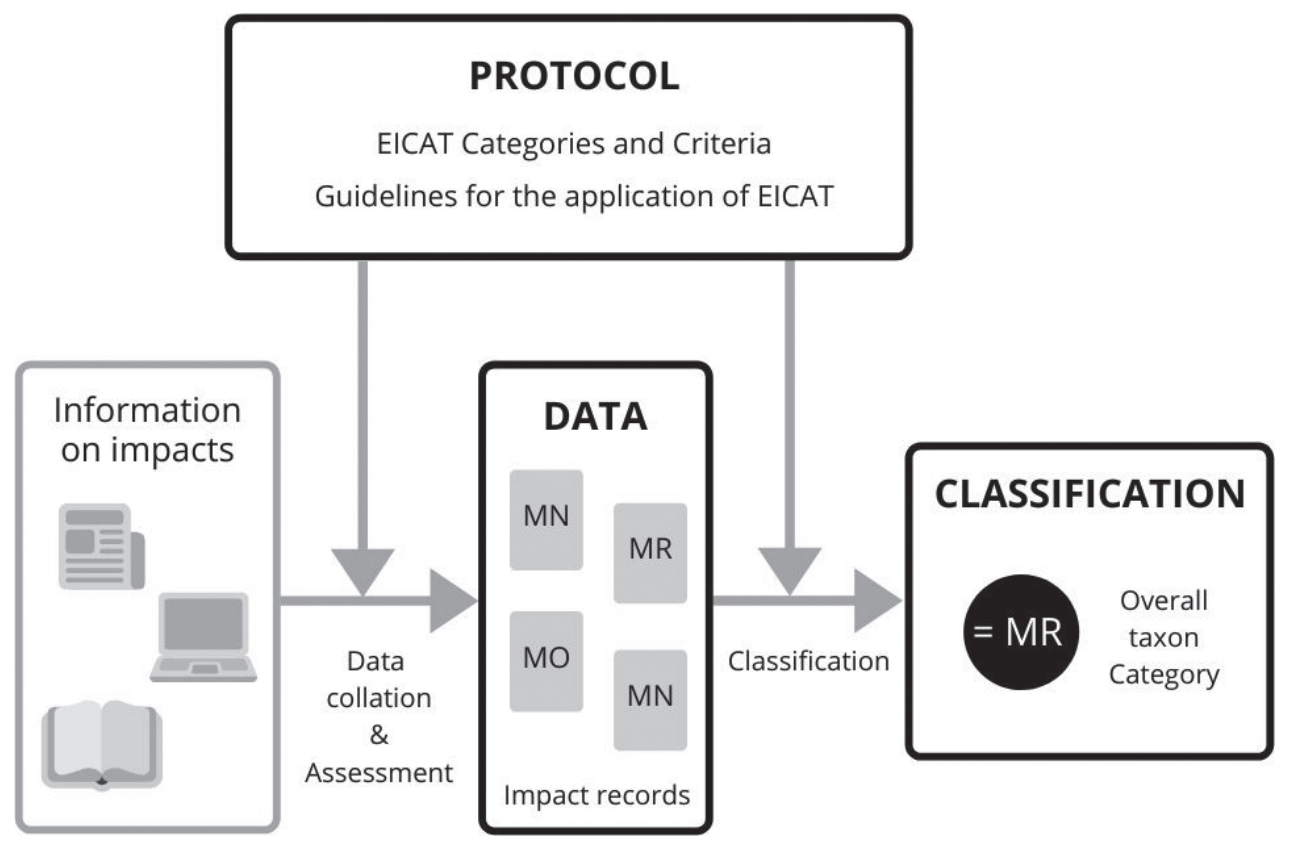

Figure I. The three elements of EICAT (black boxes). Details on the terms can be found in Boxes 1 and 2. This will be followed by submission to the IUCN EICAT Authority and review. Once approved, results will be published online. For details on these later steps, see IUCN 2020a, b. MN = Minor; MO = Moderate; $\mathbf{M R}=$ Major . 
https://www.iucn.org/theme/species/our-work/invasive-species/eicat; IUCN 2020a, b). The final step is the allocation of the maximum recorded impact across all the different impact records, which becomes the overall EICAT category for the taxon (Fig. 1).

Unlike the Red List (IUCN 2016), EICAT does not include information on potential impacts (Van der Colff et al. 2020). Furthermore, it distinguishes taxa with no impacts detected, but research on impacts available (classified as Minimal Concern MC) from species for which no data are available (Data Deficient DD).

\section{EICAT categories and criteria}

EICAT categories are distinct from each other, as they target different levels of organisation in the native species affected (e.g. individuals and populations, see IUCN 2020a, b; Box 1). However, within an impact category, impacts can vary in severity: for example, two alien species classified as having Major (MR) impacts are not necessarily equally as harmful to native species and the environment as a whole. To have MR impacts, both of these alien species would have, at least, caused the local disappearance of a subpopulation of a native species (but this disappearance would be reversible if the alien species were no longer present in the affected site, as per IUCN 2020a, b). However, EICAT does not specify, for example: (i) how abundant the native species was before the arrival of the alien species, (ii) what function the lost native species had in the environment and (iii) to what extent this function can be replaced by the alien species or other natives. Furthermore, EICAT classifications do not directly make it obvious how many native species are affected - sometimes only one native species declines due to an alien species, in other cases whole communities change their structure. Data on which, and consequently how many, native species are affected can be extracted from the EICAT data (at least, if records for these impacts are available). On that note, we would like to encourage authors of primary impact studies to publish the list of affected species to aid this process.

\section{Taxa assessed}

The EICAT protocol has been applied to a broad variety of taxonomic groups, mainly for research purposes. This includes the following: birds (e.g. Evans et al. 2016), amphibians (Kumschick et al. 2017), reptiles (Kraus 2015), some gastropods (Kesner and Kumschick 2018), some marine fish (Galanidi et al. 2018), bamboos (Canavan et al. 2019) and some mammals (Hagen and Kumschick 2018). These studies demonstrate that EICAT is applicable across a wide range of taxa and habitats. To date, none of these assessments has been reviewed and approved by the EICAT Authority (the body established to govern EICAT assessments; IUCN 2020a, b), as these formal processes are still being developed. This step will be a necessary requirement for EICAT assessments to be accepted and published by IUCN and to ensure consistent application of the protocol. Furthermore, many taxa have not yet been formally assessed with EICAT at a global level. 
EICAT assessments for all alien taxa, not only taxa with harmful impacts [Moderate (MO) or higher], will be made available through an online database linked with the IUCN Global Invasive Species Database (GISD). This means that assessments of alien taxa, for which there are no impact data (DD; Box 1), taxa for which the evidence available shows they do not affect the performance of native individuals (MC) and taxa with very low impacts (MN), will also all be made available. Taxa classified as having No Alien Population (NA) and Not Evaluated (NE) will not be included in the EICAT database. Despite the intended use for alien species and populations, the categories and criteria can, with small adaptations, also be applied to native taxa in their native ranges (see, for example, Canavan et al. 2019). Even though assessments on native species impacts will not be accepted by IUCN as part of EICAT, they can nonetheless provide important information for conservation managers and policy-makers.

\section{Geographic scale of assessments}

A taxon's EICAT classification may differ depending on the geographic scale under consideration. Sub-global (e.g. regional, national or habitat-specific) EICAT assessments only include information on impacts from a specific region or habitat, as opposed to global EICAT assessments which should include information from anywhere in the global alien range. Examples of completed sub-global assessments include alien grasses (Visser et al. 2017) and alien fish (Marr et al. 2017) in South Africa and mammals, amphibians and reptiles on Cuba (Borroto-Paez et al. 2015; Borroto-Paez and Manica 2017). Assessments can also be undertaken at smaller scales if data availability allows, as for terrestrial invasions on Marion and Prince Edward Islands (Greve et al. 2017) and for the black locust tree (Robinia pseudoacacia) in Europe, where habitatspecific EICAT assessments were produced (Branquart et al. 2016). For example, such classifications can be useful to provide information for local management actions or reporting on the status of an invasion in a region (e.g. van Wilgen and Wilson 2018 for South Africa), but will not be reviewed by IUCN or displayed on the EICAT website. However, country-specific data on impacts and their associated EICAT classifications are planned to be included in the Global Register for Introduced and Invasive Species (GRIIS; http://www.griis.org/about.php; Pagad et al. 2018). These data can complement global assessments as country assessors might have access to local grey literature like reports and databases which are often written in local languages. Such assessments might unlock these data which can subsequently be added to the global EICAT data on the IUCN EICAT platform.

\section{Appropriate use of EICAT}

There are many contexts in which EICAT can be used, ranging from policy-making and conservation planning, to research, education and communication with the pub- 
lic. In Table 1, we outline some specific uses. These are all based on a standardised application of EICAT, as described in previously-published guidelines and standards (IUCN 2020a, b) or else the (potential) modifications are specified. In the following paragraphs, we provide background on some major uses as outlined in Table 1 and previous applications and uses of EICAT.

\section{Policy and legislation}

One of the responses to threats by alien species globally has been the development of local, national and international policies (Turbelin et al. 2017). The development of regulations on alien species, in most cases, includes lists of species to be regulated, for example, to implement control actions or trade restrictions (e.g. Essl et al. 2011; García-de-Lomas and Vilà 2015). Such lists need to be developed in a manner that adheres to international agreements, such as the International Plant Protection Convention (IPPC; FAO 1996), the World Organisation for Animal Health (OIE 2011) and the World Trade Organisation (Shine et al. 2000) and need to follow best practices including, for example, transparency and evidence-based decision-making (Roy et al. 2018). EICAT has been used to contribute to processes leading up to policy-making and the development of lists and regulations as a transparent and evidence-based tool (Pergl et al. 2016; Roy et al. 2019). It is also an integral part of the risk analysis framework used to underpin the listing of alien taxa under South African national regulations (DEA 2014; Kumschick et al. 2020a, b). Furthermore, it is used in Europe as a reference to select species that will undergo full risk assessment for inclusion in the list of Invasive Alien Species of Union Concern (Regulation 1143/2014) and related national lists (Bertolino et al. 2020).

However, it must be stressed that EICAT, in itself, does not constitute a risk assessment and should not be used as one. Impact assessment tools like EICAT provide useful information on environmental impacts which may provide information for the process of risk assessment. However, risk assessments require additional information on the likelihood of the hazard occurring, such as the probability that the alien taxon will enter, establish and spread at a certain site. For policy-making and legislative decisions, additional information on benefits, costs and efficiency of management options are required (Kumschick et al. 2020; Vimercati et al. 2020; Bertolino et al. 2020).

\section{Conservation planning}

Many of the processes feeding into policy-making and the regulation of alien taxa also apply to conservation planning and the setting of management priorities, i.e. there is a large overlap between the two as priority setting is also needed for policy-making (e.g. McGeoch et al. 2016; Booy et al. 2017; Kumschick et al. 2020a). In each case, impact is an important factor to be taken into account for decision-making and EICAT has been put forward as a suitable protocol for this purpose (McGeoch et al. 2016). For example, 
Table I. Ways in which the EICAT protocol, data and classification can be used, with selected, not exhaustive examples on appropriate and inappropriate applications for those uses. The structure and content of this table are based on the Guidelines for appropriate uses of IUCN Red List data (IUCN 2016). "Additional information recommended" presents examples only and is not a comprehensive list of factors to be considered. $\mathbf{M C}=$ Minimal Concern; $\mathbf{M N}=$ Minor; $\mathbf{M O}=$ Moderate; $\mathbf{M R}=$ Major; $\mathbf{M V}=$ Massive; DD = Data Deficient (see Box 1 for descriptions).

\begin{tabular}{|c|c|c|c|}
\hline Types of uses & Appropriate uses & Inappropriate uses & $\begin{array}{c}\text { Additional information } \\
\text { recommended }\end{array}$ \\
\hline \multicolumn{4}{|c|}{ Policy and legislation } \\
\hline $\begin{array}{l}\text { International/ } \\
\text { national/ sub- } \\
\text { national legislation } \\
\text { and policy }\end{array}$ & $\begin{array}{c}\text { EICAT can provide information for the development of: } \\
\text { - International and national strategies to manage } \\
\text { biological invasions } \\
\text { - International, national, regional and local } \\
\text { regulations on alien and invasive species }\end{array}$ & $\begin{array}{l}\text { Putting an alien taxon on a } \\
\text { regulated list just because of its } \\
\text { EICAT classification }\end{array}$ & $\begin{array}{l}\text { - invasion potential } \\
\text { - management options } \\
\text { - local conditions }\end{array}$ \\
\hline $\begin{array}{l}\text { International } \\
\text { agreements }\end{array}$ & $\begin{array}{c}\text { Guiding and providing information for decisions in } \\
\text { international conventions and agreements, including: } \\
\text { - Convention on Biological Diversity (CBD) } \\
\text { - Sustainable Development Goals (SDG) } \\
\text { - International Plant Protection Convention (IPPC) } \\
\text { - World Organisation for Animal Health (OIE) }\end{array}$ & $\begin{array}{l}\text { Automatically banning an alien } \\
\text { species from trade because of } \\
\text { its EICAT classification (e.g. } \\
\text { assuming a high global impact } \\
\text { category mean this impact will } \\
\text { occur anywhere in its alien range) }\end{array}$ & $\begin{array}{l}\text { - likelihood of the impact } \\
\text { occurring } \\
\text { - mechanism of impact, taxa } \\
\text { and habitats affected }\end{array}$ \\
\hline \multicolumn{4}{|c|}{ Development planning and environmental review } \\
\hline $\begin{array}{l}\text { Regional and } \\
\text { national resource } \\
\text { management and } \\
\text { development }\end{array}$ & $\begin{array}{l}\text { Using EICAT data to provide information for natural } \\
\text { resource management at various scales in conjunction } \\
\text { with other information }\end{array}$ & $\begin{array}{l}\text { Relying solely on information } \\
\text { from EICAT for local planning } \\
\text { (e.g. using EICAT for deciding } \\
\text { which trees to plant for forestry) }\end{array}$ & $\begin{array}{l}\text { - other properties of the } \\
\text { resource } \\
\text { - economic considerations } \\
\text { - demand for resource }\end{array}$ \\
\hline $\begin{array}{l}\text { Site-level } \\
\text { planning and } \\
\text { Environmental } \\
\text { Impact Assessment } \\
\text { (EIA) }\end{array}$ & $\begin{array}{c}\text { EICAT can be used to feed into site level evaluation and } \\
\text { EIA (e.g. using or adapting EICAT protocol to assess } \\
\text { magnitude of impacts at site) }\end{array}$ & $\begin{array}{l}\text { Relying solely on information } \\
\text { from EICAT for site-level } \\
\text { planning (e.g. assuming the level } \\
\text { of impact at the site is currently } \\
\text { that of the global or national } \\
\text { EICAT category) }\end{array}$ & $\begin{array}{l}\text { - presence and abundance of } \\
\text { the alien taxa at the site } \\
\text { - native taxa at risk } \\
\text { - vulnerability of the habitat } \\
\text { at the site } \\
\text { - resources to be protected } \\
\text { - other pressures }\end{array}$ \\
\hline \multicolumn{4}{|c|}{ Conservation planning } \\
\hline $\begin{array}{l}\text { Providing } \\
\text { information for } \\
\text { conservation } \\
\text { action for native } \\
\text { species }\end{array}$ & $\begin{array}{l}\text { EICAT data can provide important information on } \\
\text { impacts to native species by alien taxa }\end{array}$ & $\begin{array}{l}\text { Managing an alien taxon solely } \\
\text { based on its impact on a specific } \\
\text { native species. }\end{array}$ & $\begin{array}{l}\text { - other pressures on native } \\
\text { species } \\
\text { - potential impact of native } \\
\text { species }\end{array}$ \\
\hline $\begin{array}{l}\text { Risk assessment of } \\
\text { alien species }\end{array}$ & $\begin{array}{l}\text { EICAT data and classifications can be used to provide } \\
\text { information for risk assessment procedure }\end{array}$ & $\begin{array}{l}\text { EICAT classification alone should } \\
\text { not be used to evaluate the level of } \\
\text { risk posed by an alien species. A } \\
\text { global classification as "harmful" } \\
\text { (MO or higher) of a taxon does } \\
\text { not necessarily imply a risk for the } \\
\text { target region }\end{array}$ & $\begin{array}{l}\text { - likelihood of the alien } \\
\text { taxon to enter, establish and } \\
\text { spread in the risk area }\end{array}$ \\
\hline $\begin{array}{l}\text { Providing } \\
\text { information for } \\
\text { management of } \\
\text { alien species }\end{array}$ & $\begin{array}{l}\text { EICAT data and classifications can feed into } \\
\text { prioritisation of alien taxa for management }\end{array}$ & $\begin{array}{c}\text { EICAT classification alone should } \\
\text { not be used to justify management } \\
\text { actions against an alien taxon. A } \\
\text { classification as "harmful" (MO } \\
\text { or higher) of a taxon does not } \\
\text { necessarily warrant or require } \\
\text { action }\end{array}$ & $\begin{array}{l}\text { - practicality and cost of } \\
\text { management } \\
\text { - likelihood of the taxon } \\
\text { to cause impacts at the } \\
\text { management site }\end{array}$ \\
\hline $\begin{array}{l}\text { Prioritising } \\
\text { management of } \\
\text { regions threatened } \\
\text { by biological } \\
\text { invasions }\end{array}$ & $\begin{array}{l}\text { EICAT data and classifications can feed into site } \\
\text { prioritisation }\end{array}$ & $\begin{array}{l}\text { The presence of an alien taxon } \\
\text { classified as "harmful" (MO } \\
\text { or higher) at a site does not } \\
\text { necessarily warrant action. }\end{array}$ & $\begin{array}{l}\text { - site-specific conditions } \\
\text { with regards to the alien } \\
\text { taxon } \\
\text { - local impact (actual and } \\
\text { potential) } \\
\text { - features of the region to be } \\
\text { protected } \\
\text { - local management options }\end{array}$ \\
\hline $\begin{array}{l}\text { Geographic priority } \\
\text { setting: site-level, } \\
\text { landscape/seascape } \\
\text { level and global } \\
\text { level }\end{array}$ & $\begin{array}{l}\text { Using EICAT protocol, data and classifications to } \\
\text { support site priority setting by providing information } \\
\text { on the impacts to native species (both current and } \\
\text { potential) within sites of conservation importance }\end{array}$ & $\begin{array}{c}\text { Using EICAT data and } \\
\text { classifications (especially global } \\
\text { EICAT classifications of an alien } \\
\text { taxon) on their own to prioritise } \\
\text { sites }\end{array}$ & $\begin{array}{c}\text { - site-specific conditions } \\
\text { - local impact (actual and } \\
\text { potential) } \\
\text { - features of the site to be } \\
\text { protected }\end{array}$ \\
\hline
\end{tabular}




\begin{tabular}{|c|c|c|c|}
\hline Types of uses & Appropriate uses & Inappropriate uses & $\begin{array}{l}\text { Additional information } \\
\text { recommended }\end{array}$ \\
\hline \multicolumn{4}{|c|}{ Monitoring and evaluation } \\
\hline $\begin{array}{l}\text { Evaluating the } \\
\text { state of invasion } \\
\text { and monitoring } \\
\text { changes in the } \\
\text { state of invasion }\end{array}$ & $\begin{array}{l}\text { EICAT can be used as an indicator for biological } \\
\text { invasions }\end{array}$ & $\begin{array}{l}\text { Using EICAT as the only indicator } \\
\text { of the state of invasion }\end{array}$ & $\begin{array}{l}\text { - area occupied } \\
\text { - number of alien taxa } \\
\text { present }\end{array}$ \\
\hline $\begin{array}{l}\text { Measuring the } \\
\text { effectiveness and } \\
\text { impact of control } \\
\text { activities }\end{array}$ & $\begin{array}{l}\text { The EICAT protocol can be used to assess information } \\
\text { on impacts of a certain population of an alien } \\
\text { species before and after control measures have been } \\
\text { implemented at a site. The resulting data can show the } \\
\text { effectiveness of control measures and the resilience of a } \\
\text { system with regards to the impacts caused }\end{array}$ & $\begin{array}{l}\text { Management at a local scale does } \\
\text { not necessarily lead to a decrease } \\
\text { in the impacts of a species at a } \\
\text { global scale. Furthermore, the } \\
\text { global impact classifications, as } \\
\text { supported by IUCN, are not } \\
\text { suitable to reflect changes in } \\
\text { impacts due to management } \\
\text { actions, as they consist of the } \\
\text { maximum impact ever recorded }\end{array}$ & $\begin{array}{l}\text { - local impacts } \\
\text { - native taxa affected }\end{array}$ \\
\hline $\begin{array}{l}\text { Documenting } \\
\text { species with low } \\
\text { impacts }\end{array}$ & $\begin{array}{c}\text { EICAT does not only allow for the classification of } \\
\text { severe impacts, but it ranges from classifying evidence } \\
\text { on no and low impacts on native species (MC and } \mathbf{M N} \text {, } \\
\text { respectively) up to high impacts. This should encourage } \\
\text { the publication of results of taxa which had low impacts } \\
\text { on the recipient systems. }\end{array}$ & $\begin{array}{c}\text { Species which are classified as } \\
\text { causing impacts that are of MC } \\
\text { MN should not automatically be } \\
\text { considered as safe or to pose no risk. } \\
\text { These low impacts could be found } \\
\text { for several reasons, for example: } \\
\text { i) the alien species does not and } \\
\text { will not have high impacts, ii) the } \\
\text { introduced populations have not } \\
\text { had the opportunity to cause high } \\
\text { impacts due to, for example, lag } \\
\text { times or low abundance, iii) there is } \\
\text { a lack of data on impact such that } \\
\text { the scored impact is lower than the } \\
\text { actual impact }\end{array}$ & $\begin{array}{l}\text { - time since introduction } \\
\text { - abundance of alien taxon }\end{array}$ \\
\hline $\begin{array}{l}\text { Documenting } \\
\text { ecosystem recovery } \\
\text { after control (e.g. } \\
\text { extirpation or } \\
\text { eradication) }\end{array}$ & $\begin{array}{l}\text { The EICAT protocol can be used to classify studies on } \\
\text { impacts or legacy effects after an alien taxon has been } \\
\text { removed and can facilitate the understanding of whether } \\
\text { these impacts are reduced after removal }\end{array}$ & $\begin{array}{l}\text { EICAT data should not be used } \\
\text { as sole evidence for successful } \\
\text { restoration }\end{array}$ & $\begin{array}{l}\text { - native taxa recovery } \\
\text { - other stressors on the site }\end{array}$ \\
\hline \multicolumn{4}{|l|}{ Scientific research } \\
\hline $\begin{array}{l}\text { Providing } \\
\text { information for } \\
\text { species-specific } \\
\text { studies }\end{array}$ & $\begin{array}{c}\text { Use gaps identified in the information on impacts of } \\
\text { species or lack thereof (e.g. species classified as DD), to } \\
\text { guide research }\end{array}$ & $\begin{array}{l}\text { EICAT classifications do not } \\
\text { replace field studies: field studies } \\
\text { are needed to populate EICAT }\end{array}$ & $\begin{array}{l}\text { - detection of a new alien } \\
\text { taxon at a site }\end{array}$ \\
\hline $\begin{array}{l}\text { Providing } \\
\text { information } \\
\text { for research on } \\
\text { multiple species } \\
\text { and invasion } \\
\text { processes }\end{array}$ & $\begin{array}{c}\text { Using EICAT data to show patterns and trends related } \\
\text { to alien species impacts, including potential future } \\
\text { threats }\end{array}$ & $\begin{array}{c}\text { Assuming a change in EICAT } \\
\text { score means a change in impact } \\
\text { without considering the likelihood } \\
\text { of the change being observed due } \\
\text { to improved knowledge }\end{array}$ & $\begin{array}{l}\text { - pathways transporting } \\
\text { alien taxa } \\
\text { - sites vulnerable to alien } \\
\text { taxa }\end{array}$ \\
\hline $\begin{array}{l}\text { Predicting impacts } \\
\text { of alien species }\end{array}$ & $\begin{array}{c}\text { EICAT data can feed into trait-based, mechanistic and } \\
\text { species interaction studies and can generate testable } \\
\text { hypotheses }\end{array}$ & $\begin{array}{l}\text { EICAT classifications cannot - in } \\
\text { isolation - predict impacts of a } \\
\text { taxon in a new region }\end{array}$ & $\begin{array}{l}\text { - traits of alien taxa } \\
\text { - invasion history }\end{array}$ \\
\hline \multicolumn{4}{|c|}{ Education, communication and awareness raising } \\
\hline \begin{tabular}{l|l} 
Education & \\
\end{tabular} & $\begin{array}{c}\text { Providing information for academic work across } \\
\text { educational levels, for example, school assignments, } \\
\text { undergraduate essays and dissertations }\end{array}$ & $\begin{array}{l}\text { Use EICAT data as only } \\
\text { information about risks of alien } \\
\text { species }\end{array}$ & $\begin{array}{l}\text { - invasion history } \\
\text { - vulnerable habitats }\end{array}$ \\
\hline $\begin{array}{l}\text { Media and } \\
\text { awareness raising }\end{array}$ & $\begin{array}{l}\text { Promoting knowledge and awareness on alien species, } \\
\text { their impacts on native biodiversity, biodiversity } \\
\text { conservation issues, risks to biodiversity }\end{array}$ & $\begin{array}{l}\text { A high EICAT category does } \\
\text { not imply an alien species has } \\
\text { no benefits and that control } \\
\text { and regulation should not take } \\
\text { stakeholders into account }\end{array}$ & $\begin{array}{l}\text { - benefits of taxa } \\
\text { - conflicts of interest }\end{array}$ \\
\hline Fund-raising & $\begin{array}{l}\text { Providing a solid evidence-base for funding proposals } \\
\text { to engage in work on alien species and conservation of } \\
\text { native biodiversity }\end{array}$ & & project dependent \\
\hline
\end{tabular}

Katsanevakis et al. (2016) adapted and used EICAT to aid prioritisation of conservation actions in the Mediterranean Sea. The principles of EICAT - adapted to a questionnaire - have also been used as part of a decision-support scheme for alien species management in cities and been applied in Cape Town, South Africa (Gaertner et al. 2017). 
Ideally, EICAT should not be used in isolation to set management priorities (as also outlined in Branquart et al. 2016), especially for already established alien taxa. However, EICAT can be useful as an early warning system for taxa which have been shown to cause harmful impacts in other areas to which they were introduced and so could be considered a "rapid response" tool. When resources are limited and decisions need to be taken without delay, EICAT can provide useful information on potentially harmful taxa, allowing prioritisation of their interception at borders or rapid management actions for new incursions. EICAT shows the maximum impact ever recorded for certain populations of an alien taxon and collates all records of impact for the taxon. It is, therefore, a useful reference to select the most harmful taxa, providing an overview of how they impact native species and ecosystems. To set management priorities for alien taxa most effectively, their current and potential future local impact should be considered and EICAT can clearly contribute to assessing the former, but could also be used for prioritising species for the latter. Nevertheless, where possible, additional information should be taken into account, including, for example, the distribution and the invasion potential of the taxon in the region to be managed, management options available and their costs and effectiveness. The same applies when setting priorities for site and pathway management. EICAT data can be useful to assess which pathways facilitate the movement of more harmful taxa (Pergl et al. 2017) or which regions are more at risk due to high-impacting aliens being present there (Nentwig et al. 2010). However, managing a pathway is not necessarily needed just because it contains harmful taxa (MO, MR, MV) and a taxon with a high impact elsewhere does not necessarily have the same impact in the region of interest. Nevertheless, EICAT provides important information feeding into prioritisation processes for alien taxa, especially considering that the main justification for management, in many cases, is their negative impacts (e.g. McGeoch et al. 2016; Roy et al. 2019).

\section{Monitoring and evaluation}

Simple and understandable indicators can be produced from EICAT to track changes in the magnitude of environmental impacts from alien species over time. This can provide information for policy processes at the global level, such as the CBD Strategic Plan, UN Sustainable Development Goals and the Intergovernmental Science-Policy Platform on Biodiversity and Ecosystem Services (IPBES) or at the national level to support the monitoring of management measures. For example, EICAT has been recommended as a tool to monitor biological invasions globally and is listed as one of three essential variables to report on when monitoring biological invasions at country level (Latombe et al. 2017). The number and identity of taxa in each impact category, for example, can give an indication of how many (potentially) harmful taxa are present in the country and, if collected over time, can be used to track trends in the impacts of these taxa. Furthermore, impact is one of the main indicators used to provide information for reports on the status of alien taxa in a country (Wilson et al. 2018). 


\section{Scientific research}

Aside from the availability (or lack) of data on impacts, the sky is the limit for the uses of EICAT for research. The questions which EICAT can help to answer are diverse, but due to the nature of the system are focussed around topics related to the magnitude and type of alien species' environmental impacts and the availability of impact data.

The most basic application of EICAT enables alien species with severe impacts to be distinguished from those which are less harmful, at least on the basis of available data. This allows comparisons of species with different reported levels of impact, which have been made within taxonomic groups, including birds (Evans et al. 2016), amphibians (Kumschick et al. 2017), fish (Galanidi et al. 2018) and bamboos (Canavan et al. 2019). EICAT data can also be used to compare impact magnitudes between taxonomic groups (similarly to Kumschick et al. 2015). Comparisons need to be interpreted with caution, as the absence of evidence of impacts does not mean that no impacts are occurring (see, for example, Hulme et al. 2013); however, empirical studies can only ever proceed on the basis of what data are available (Blackburn et al. 2015).

The ways in which alien taxa affect native species can differ between taxonomic groups or habitats. EICAT has been used to show that the importance of mechanisms can differ between groups of insects (McGeoch et al. 2015), amphibians and reptiles (Kraus 2015), birds (Evans et al. 2016) and gastropods (Kesner and Kumschick 2018). Some impact mechanisms are associated with more harmful impacts (Evans et al. 2016; Rockwell-Postel et al. 2020). Furthermore, the available data suggest that certain regions are more highly impacted by alien species than others. Assessing which regions are more highly impacted and improving our ability to understand why, can aid in setting priorities for management and resource allocation (e.g. Evans et al. 2016), albeit that spatial biases in the literature (e.g. Evans and Blackburn 2020) should be considered when interpreting such findings. Similarly, certain habitats could be more vulnerable to impacts by certain taxa, as in the case of Robinia pseudoacacia, which affects open habitats like grasslands more severely than closed, forested habitats (Branquart et al. 2016).

Theory suggests that species traits should play a role in their invasiveness and impacts. EICAT can be useful to study patterns related to the traits of alien species with and without harmful impacts (e.g. Evans et al. 2018a). It has also been used to test general invasion hypotheses related to the severity of impacts of alien taxa, such as the island susceptibility hypothesis (Hagen and Kumschick 2018). Additionally, studies indicate that we lack information on the environmental impacts of many alien species (Simberloff et al. 2013; Kumschick et al. 2015; Evans et al. 2016). EICAT provides a structured way to identify data gaps and can, therefore, help to set priorities for future impact research (Evans et al. 2018b; Evans and Blackburn 2020). 


\section{Education, communication and awareness raising}

EICAT provides a solid base for communicating the breadth and diversity of impacts which alien taxa can cause on the environment and the range in magnitude of those impacts. Other communication tools have been put forward to achieve the same goal, including the "100 of the world's worst invaders" list compiled by experts of the IUCN Invasive Species Specialist Group (Lowe et al. 2004) or the "100 worst list" of the European Union (Vila et al. 2009) and more recently using a similar impact scoring approach for European aliens (Nentwig et al. 2018). One of the main advantages of the EICAT approach compared to a "100 worst list" is that it showcases not only species with high impacts, but also gives the range in known magnitudes of impact caused by different alien taxa.

One particular communication value of EICAT is that it translates a complex issue - the magnitude of environmental impacts from alien taxa - into a simple but welldefined set of categories. It has been repeatedly used for this purpose in scientific papers studying certain organisms, for example, giant African land snails (Achatina fulica) on Christmas Island (O'Loughlin and Green 2017), crayfish spp. in parts of the USA (DiStefano et al. 2015), the anole lizard (Anolis porcatus) in Brazil (Prates et al. 2016) and red king crab (Paralithodes camtschaticus) on the Euro-Arctic shelf (Christiansen et al. 2015). It is also a standardised tool that can be used to assess alien taxa from any taxonomic group, making it applicable across the globe. This lends itself to becoming a powerful communication tool, in much the same vein as the IUCN Red List, which shares the same characteristics, but categorises species based on their risk of extinction. As with the IUCN Red List, EICAT can be used to communicate and engage with a wide variety of audiences for different purposes.

EICAT classifications can be converted into info-graphics, or even art, to help communicate information on impacts from alien species (e.g. as done for the IUCN Red List data, https://www.sharktrust.org/shark-science or https://infowetrust.com/ endangeredsafari/), making the messages and results more attractive to print, online and on social media. EICAT can also be used by civil society organisations in supporting them in funding applications and communicating and engaging with stakeholders to raise awareness and change behaviour or support them in undertaking action on the ground. In addition, as it is an IUCN 'global standard', it is also more likely to be a known and 'trusted' information source for policy-makers, supporting scientists in bridging the science-policy interface at a national and global level.

\section{Conclusions}

EICAT has a wealth of uses and, if the protocol is correctly applied (i.e. applying the EICAT Categories and Criteria and following the Guidelines in full), can feed into a wide range of processes. EICAT provides a platform for sharing data on the impacts 
of alien species in a standardised way, which comes with several benefits. First, the capacity to act upon and control invasions differs greatly amongst countries (Early et al. 2016; Latombe et al. 2017). Standardising and globalising the process of impact assessment within a framework such as EICAT, can aid countries with less financial or technical capacity to develop policies and priorities for tackling biological invasions, as it provides a resource on impacts of invasions to tap into. It also highlights priorities for regional biosecurity (Faulkner et al. 2020). Second, it is a versatile protocol which allows for the regular updating of information. Since all the sources considered for each classification are provided in the EICAT data, anyone can, and should be encouraged to, add relevant missing information. This is also an opportunity for less accessible sources of information to be added to the impact database.

That said, for some uses, it might be beneficial to deviate from the EICAT protocol or to extract only certain information from the EICAT data. For example, the use of expert opinion on impact magnitudes, in addition to or instead of written reports, can be justified for feeding into local management recommendations (e.g. Zengeya et al. 2017; Carboneras et al. 2018; Bertolino et al. 2020). This can be legitimate and reflects the original authors' intent to develop a broadly applicable and versatile system (Blackburn et al. 2014), but these deviations from the standard process should be adequately described and acknowledged to avoid confusion with the official, standardised process as established and administered by IUCN. Furthermore, data and classifications produced during such non-standardised exercises will not be accepted by IUCN for incorporation into the official EICAT process or displayed on the website. Nevertheless, they can, in some cases, provide a starting point for, or feed into, standardised assessments.

\section{Acknowledgements}

This paper emerged from a workshop on 'Frameworks used in Invasion Science' hosted by the DSI-NRF Centre of Excellence for Invasion Biology in Stellenbosch, South Africa, 11-13 November 2019, that was supported by the National Research Foundation of South Africa and Stellenbosch University. We thank John Wilson, Joyce Ntuli, Menzi Nxumalo, Deah Lieurance, David Strayer and an anonymous reviewer for helpful comments on an earlier draft of the manuscript. SK acknowledges the support of the DSI-NRF Centre of Excellence for Invasion Biology (CIB) and Stellenbosch University and the South African Department of Environment, Forestry and Fisheries (DEFF) noting that this publication does not necessarily represent the views or opinions of DEFF or its employees. HER supported by the Natural Environment Research Council award number NE/R016429/1 as part of the UK-SCAPE programme delivering National Capability. TE is supported by the Alexander von Humboldt Foundation. SvB is supported by the Swiss National Science Foundation (grants no. 31003A_179491 and 31BD30_184114) and the Belmont Forum - BiodivERsA International joint call project InvasiBES (PCI2018-092939). The views expressed in this publication do not necessarily reflect those of IUCN. 


\section{References}

Bacher S, Blackburn TM, Essl F, Genovesi P, Heikkilä J, Jeschke JM, Jones G, Keller R, Kenis M, Kueffer C, Martinou AF, Nentwig W, Pergl J, Pyšek P, Rabitsch W, Richardson DM, Roy HE, Saul W-C, Scalera R, Vilà M, Wilson JRU, Kumschick S (2018) Socio-economic impact classification of alien taxa (SEICAT). Methods in Ecology and Evolution 9: 159-168. https://doi.org/10.1111/2041-210X.12844

Bertolino S, Ancillotto L, Bartolommei P, Benassi G, Capizzi D, Gasperini S, Lucchesi M, Mori E, Scillitani L, Sozio G, Falaschi M, Ficetola GF, Cerri J, Genovesi P, Carnevali L, Loy A, Monaco A (2020) A framework for prioritising present and potentially invasive mammal species for a national list. In: Wilson JR, Bacher S, Daehler CC, Groom QJ, Kumschick S, Lockwood JL, Robinson TB, Zengeya TA, Richardson DM (Eds) Frameworks used in Invasion Science. NeoBiota 62: 31-54. https://doi.org/10.3897/neobiota.62.52934

Blackburn TM, Bacher S, Genovesi P, Jeschke JM, Kumschick S, Richardson DM, Essl F, Hulme PE, Kühn I, Nentwig W, Pergl J, Rabitsch W, Vilà M, Wilson JRU, Pyšek P (2015) Tools to address invasive species impacts must build on knowledge not ignorance - some thoughts on Ojaveer et al. PLoS Biology. http://www.plosbiology.org/annotation/listThread.action? root=86349

Blackburn TM, Essl F, Evans T, Hulme PE, Jeschke JM, Kühn I, Kumschick S, Mrugała A, Marková Z, Nentwig W, Pergl J, Pyšek P, Rabitsch W, Ricciardi A, Richardson DM, Sendek A, Vilà M, Wilson JRU, Winter M, Genovesi P, Bacher S (2014) A unified classification of alien species based on the magnitude of their environmental impacts. PLoS Biology 12(5): e1001850. https://doi.org/10.1371/journal.pbio.1001850

Booy O, Mill AC, Roy HE, Hiley A, Moore N, Robertson P, Baker S, Brazier M, Bue M, Bullock R, Campbell S, Eyre D, Foster J, Hatton-Ellis M, Long J, Macadam C, MorrisonBell C, Mumford J, Newman J, Parrott D, Payne R, Renals T, Rodgers E, Spencer M, Stebbing P, Sutton-Croft M, Walker KJ, Ward A, Whittaker S, Wyn G (2017) Risk management to prioritise the eradication of new and emerging invasive non-native species. Biological Invasions 19: 2401-2417. https://doi.org/10.1007/s10530-017-1451-z

Borroto-Paez R, Bosch RA, Fabres BA, Garcia OA (2015) Introduced amphibians and reptiles in the Cuban Archipelago. Herpetological Conservation and Biology 10: 985-1012.

Borroto-Paez R, Mancina CA (2017) Biodiversity and conservation of Cuban mammals: past, present, and invasive species. Journal of Mammalogy 98: 964-985. https://doi. org/10.1093/jmammal/gyx017

Branquart E, D'hondt B, Vanderhoeven S, Kumschick S (2016) From impact studies to management actions: practicing risk analysis of introduced trees. In: Krumm F, Vitkova L (Eds) Introduced Tree Species in European Forests: Opportunities and Challenges. European Forest Institute, Joensuu, Finland, 124-136.

Canavan S, Kumschick S, Le Roux JJ, Richardson DM, Wilson JRU (2019) Does origin determine environmental impacts? Not for bamboos. Plants, People, Planet 1(2): 119-128. https://doi.org/10.1002/ppp3.5 
Carboneras C, Genovesi P, Vila M, Blackburn TM, Carrete M, Clavero M, D’Hondt B, Orueta JF, Gallardo B, Geraldes P, Gonzalez-Moreno P, Gregory RD, Nentwig W, Paquet JY, Pyšek P, Rabitsch W, Ramirez I, Scalera R, Tella JL, Walton P, Wynde R (2018) A prioritised list of invasive alien species to assist the effective implementation of EU legislation. Journal of Applied Ecology 55: 539-547. https://doi.org/10.1111/1365-2664.12997

CBD [Convention on Biological Diversity] (2014) COP XII Decision 17. The $12^{\text {th }}$ Conference of the Parties of the Convention on Biological Diversity Decision 17. Pyeongchang, Republic of Korea, 6-17 October 2014. https://www.cbd.int/decision/cop/?id=13380 [accessed 1 February 2020]

CBD [Convention on Biological Diversity] (2018) COP XIV Decision 14/11. The $14^{\text {th }}$ Conference of the Parties of the Convention on Biological Diversity Decision 17. Sharm ElSheikh, Egypt, 17-29 November 2018. https:/www.cbd.int/decisions/cop/?m=cop-14 [accessed 1 February 2020]

Christiansen JS, Sparboe M, Saether BS, Siikavuopio SI (2015) Thermal behaviour and the prospect spread of an invasive benthic top predator onto the Euro-Arctic shelves. Diversity and Distributions 21: 1004-1013. https://doi.org/10.1111/ddi.12321

DEA [Department of Environmental Affairs] (2014) National Environmental Management: Biodiversity Act 2004 (Act No. 10 of 2004) Alien and Invasive Species Regulations, 2014. Government Gazette Vol. 590, No. 37885.

DiStefano RJ, Imhoff EM, Swedberg DA, Boersig TC (2015) An analysis of suspected crayfish invasions in Missouri, USA: evidence for the prevalence of short-range translocations and support for expanded survey efforts. Management of Biological Invasions 6: 395-411. https://doi.org/10.3391/mbi.2015.6.4.08

Early R, Bradley BA, Dukes JS, Lawler JJ, Olden JD, Blumenthal DM, Gonzalez P, Grosholz ED, Ibañez I, Miller LP, Sorte CJB, Tatem AJ (2016) Global threats from invasive alien species in the twenty-first century and national response capacities. Nature Communications 7: 12485. https://doi.org/10.1038/ncomms12485

Essl F, Nehring S, Klingenstein F, Milasowszky N, Nowack C, Rabitsch W (2011) Review of risk assessment systems of IAS in Europe and introducing the German-Austrian Black List Information system (GABLIS). Journal for Nature Conservation 19: 339-350. https://doi. org/10.1016/j.jnc.2011.08.005

Evans T, Blackburn TM (2020) Global variation in the availability of data on the environmental impacts of alien birds. Biological Invasions 22: 1027-1036. https://doi.org/10.1007/ s10530-019-02153-z

Evans T, Kumschick S, Blackburn TM (2016) Application of the Environmental Impact Classification for Alien Taxa (EICAT) to a global assessment of alien bird impacts. Diversity and Distributions 22: 919-931. https://doi.org/10.1111/ddi.12464

Evans T, Kumschick S, Dyer EE, Blackburn TM (2014) Comparing determinants of alien bird impacts across two continents: implications for risk assessment and management. Ecology and Evolution 4: 2957-2967. https://doi.org/10.1002/ece3.1144 
Evans T, Kumschick S, Sekercioglu CH, Blackburn TM (2018a) Identifying the factors that determine the magnitude and type of alien bird impacts. Diversity and Distributions 24: 800-810. https://doi.org/10.1111/ddi.12721

Evans T, Pigot A, Kumschick S, Blackburn TM (2018b) Determinants of Data Deficiency in the impacts of alien bird species. Ecography 41: 1401-1410. https://doi.org/10.1111/ecog.03232

FAO [Food and Agriculture Organization of the UN] (1996) Pest risk analysis for quarantine pests. International Standards for Phytosanitary Measures Publication No. 11. FAO, Rome.

Faulkner KT, Robertson MP, Wilson JRU (2020) Stronger regional biosecurity is essential to prevent hundreds of harmful biological invasions. Global Change Biology 26(4): 2449-2462. https://doi.org/10.1111/gcb.15006

Gaertner M, Novoa A, Fried J, Richardson DM (2017) Managing invasive species in cities: a decision support framework applied to Cape Town. Biological Invasions 19: 3707-3723. https://doi.org/10.1007/s10530-017-1587-x

Galanidi M, Zenetos A, Bacher S (2018) Assessing the socio-economic impacts of priority marine invasive fishes in the Mediterranean with the newly proposed SEICAT methodology. Mediterranean Marine Science 19(1): 107-123. https://doi.org/10.12681/mms.15940

García-de-Lomas J, Vilà M (2015) Lists of harmful alien organisms: Are the national regulations adapted to the global world? Biological invasions 17(11): 3081-3091. https://doi. org/10.1007/s10530-015-0939-7

González-Moreno P, Lazzaro L, Vilà M, Preda C, Adriaens T, Bacher S, Brundu G, Copp GH, Essl F, García-Berthou E, Katsanevakis S, Moen TL, Lucy FE, Nentwig W, Roy HE, Srèbalienė G, Talgø V, Vanderhoeven S, Andjelković A, Arbačiauskas K, Auger-Rozenberg M-A, Bae M-J, Bariche M, Boets P, Boieiro M, Borges PA, Canning-Clode J, Cardigos F, Chartosia N, Cottier-Cook EJ, Crocetta F, D’hondt B, Foggi B, Follak S, Gallardo B, Gammelmo Ø, Giakoumi S, Giuliani C, Fried G, Jelaska LS, Jeschke JM, Jover M, Juárez-Escario A, Kalogirou S, Kočić A, Kytinou E, Laverty C, Lozano V, Maceda-Veiga A, Marchante E, Marchante H, Martinou AF, Meyer S, Michin D, Montero-Castaño A, Morais MC, Morales-Rodriguez C, Muhthassim N, Nagy ZA, Ogris N, Onen H, Pergl J, Puntila R, Rabitsch W, Ramburn TT, Rego C, Reichenbach F, Romeralo C, Saul W-C, Schrader G, Sheehan R, Simonović P, Skolka M, Soares AO, Sundheim L, Tarkan AS, Tomov R, Tricarico E, Tsiamis K, Uludağ A, van Valkenburg J, Verreycken H, Vettraino AM, Vilar L, Wiig Ø, Witzell J, Zanetta A, Kenis M (2019) Consistency of impact assessment protocols for non-native species. NeoBiota 44: 1-25. https://doi.org/10.3897/neobiota.44.31650

Greve M, Mathakutha R, Steyn C, Chown SL (2017) Terrestrial invasions on sub-Antarctic Marion and Prince Edward Islands. Bothalia 47: 1-21. https://doi.org/10.4102/abc.v47i2.2143

Hagen B, Kumschick S (2018) The relevance of using various scoring schemes revealed by an impact assessment of feral mammals. Neobiota 38: 37-75. https://doi.org/10.3897/ neobiota.38.23509

Hawkins CL, Bacher S, Essl F, Hulme PE, Jeschke JM, Kühn I, Kumschick S, Nentwig W, Pergl J, Pyšek P, Rabitsch W, Richardson DM, Vilà M, Wilson JRU, Genovesi P, Blackburn TM (2015) Framework and guidelines for implementing the proposed IUCN Environmental 
Impact Classification for Alien Taxa (EICAT). Diversity and Distributions 21: 1360-1363. https://doi.org/10.1111/ddi.12379

Hulme PE, Pyšek P, Jarošík V, Pergl J, Schaffner U, Vila M (2013) Bias and error in understanding plant invasion impacts. Trends in Ecology \& Evolution 28: 212-218. https://doi. org/10.1016/j.tree.2012.10.010

IUCN (2016) Guidelines for appropriate uses of IUCN Red List Data. Version 3.0. Adopted by the IUCN Red List Committee.

IUCN (2020a) IUCN EICAT Categories and Criteria. The Environmental Impact Classification for Alien Taxa (EICAT) First edition. IUCN, Gland, Switzerland and Cambridge, UK. IUCN. https://doi.org/10.2305/IUCN.CH.2020.05.en

IUCN (2020b) Guidelines for using the IUCN Environmental Impact Classification for Alien Taxa (EICAT) Categories and Criteria): First edition. Version 1.1. Gland, Switzerland and Cambridge, UK. IUCN.

Katsanevakis S, Tempera F, Teixeira H (2016) Mapping the impact of alien species on marine ecosystems: the Mediterranean Sea case study. Diversity and Distributions 22: 694-707. https://doi.org/10.1111/ddi.12429

Kesner D, Kumschick S (2018) Gastropods alien to South Africa cause severe environmental harm in their global alien ranges across habitats. Ecology and Evolution 8: 8273-8285. https://doi.org/10.1002/ece3.4385

Kraus F (2015) Impacts from invasive reptiles and amphibians. Annual Review of Ecology, Evolution, and Systematics 46: 75-97. https://doi.org/10.1146/annurev-ecolsys-112414-054450

Kumschick S, Bacher S, Marková Z, Pergl J, Pyšek P, Vaes-Petignat S, van der Veer G, Vilà M, Nentwig W (2015) Comparing impacts of alien plants and animals using a standard scoring system. Journal of Applied Ecology 52: 552-561. https://doi.org/10.1111/1365-2664.12427

Kumschick S, Blackburn TM, Richardson DM (2016) Managing alien bird species: Time to move beyond "100 of the Worst" lists? Bird Conservation International 26: 154-163. https://doi.org/10.1017/S0959270915000167

Kumschick S, Foxcroft LC, Wilson JR (2020a) Analysing the risks posed by biological invasions to South Africa. In: van Wilgen BW, Measey J, Richardson DM, Wilson JR, Zengeya TA (Eds) Biological Invasions in South Africa. Springer, Berlin, 573-595. https://doi.org/10.1007/978-3-030-32394-3_20

Kumschick S, Gaertner M, Vilà M, Essl F, Jeschke JM, Pyšek P, Ricciardi A, Bacher S, Blackburn TM, Dick JTA, Evans T, Hulme PE, Kühn I, Mrugala A, Pergl J, Rabitsch W, Richardson DM, Sendek A, Winter M (2015) Ecological impacts of alien species: quantification, scope, caveats, and recommendations. BioScience 65: 55-63. https://doi.org/10.1093/ biosci/biu 193

Kumschick S, Measey GJ, Vimercati G, de Villiers FA, Mokhatla MM, Davies SJ, Thorp CJ, Rebelo AD, Blackburn TM, Kraus F (2017) How repeatable is the Environmental Impact Classification of Alien Taxa (EICAT)? Comparing independent global impact assessments of amphibians. Ecology and Evolution 7: 2661-2670. https://doi.org/10.1002/ece3.2877

Kumschick S, Wilson JR, Foxcroft LC (2018) Framework and guidelines for conducting risk analyses for alien species. Preprints. https://doi.org/10.20944/preprints201811.0551.v1 
Kumschick S, Wilson JRU, Foxcroft LC (2020) A framework to support alien species regulation: the Risk Analysis for Alien Taxa (RAAT). In: Wilson JR, Bacher S, Daehler CC, Groom QJ, Kumschick S, Lockwood JL, Robinson TB, Zengeya TA, Richardson DM (Eds) Frameworks used in Invasion Science. NeoBiota 62: 213-239. https://doi.org/10.3897/neobiota.62.51031

Latombe G, Pyšek P, Jeschke JM, Blackburn TM, Bacher S, Capinha C, Costello MJ, Fernández M, Gregory RD, Hobern D, Hui C, Jetz W, Kumschick S, McGrannachan C, Pergl J, Roy HE, Scalera R, Squires ZE, Wilson JRU, Winter M, Genovesi P, McGeoch MA (2017) A vision for global monitoring of biological invasions. Biological Conservation 213: 295-308. https://doi.org/10.1016/j.biocon.2016.06.013

Lowe S, Browne M, Boudjelas S, De Poorter M (2004) 100 of the world's worst invasive alien species. A selection from the Global Invasive Species Database. Published by The Invasive Species Specialist Group (ISSG) a specialist group of the Species Survival Commission (SSC) of the World Conservation Union (IUCN).

Marr SM, Ellender BR, Woodford DJ, Alexander ME, Wasserman RJ, Ivey P, Zengeya T, Weyl OLF (2017) Evaluating invasion risk for freshwater fishes in South Africa. Bothalia-African Biodiversity \& Conservation 47(2): 1-10. https://doi.org/10.4102/abc.v47i2.2177

McGeoch MA, Genovesi P, Bellingham PJ, Costello MJ, McGrannachan C, Sheppard A (2016) Prioritizing species, pathways, and sites to achieve conservation targets for biological invasion. Biological Invasions 18(2): 299-314. https://doi.org/10.1007/s10530-015-1013-1

McGeoch MA, Lythe MJ, Henriksen MV, McGrannachan CM (2015) Environmental impact classification for alien insects: a review of mechanisms and their biodiversity outcomes. Current Opinion in Insect Science 12: 46-53. https://doi.org/10.1016/j.cois.2015.09.004

Nentwig W, Bacher S, Kumschick S, Pyšek P, Vilà M (2018) More than "100 worst” alien species in Europe. Biological Invasions 20: 1611-1621. https://doi.org/10.1007/s10530-017-1651-6

Nentwig W, Bacher S, Pyšek P, Vilà M, Kumschick S (2016) The Generic Impact Scoring System (GISS): a standardized tool to quantify the impacts of alien species. Environmental Monitoring and Assessment 188: 1-315. https://doi.org/10.1007/s10661-016-5321-4

Nentwig W, Kühnel E, Bacher S (2010) A generic impact-scoring system applied to alien mammals in Europe. Conservation Biology 24(1): 302-311. https://doi.org/10.1111/j.15231739.2009.01289.x

Nkuna KV, Visser V, Wilson JRU, Kumschick S (2018) Global environmental and socioeconomic impacts of selected alien grasses as a basis for ranking threats to South Africa. Neobiota 41: 19-65. https://doi.org/10.3897/neobiota.41.26599

OIE (2011) Guidelines for assessing the risk of non-native animals becoming invasive. http:// www.oie.int/fileadmin/Home/eng/Our_scientific_expertise/docs/pdf/OIEGuidelines_ NonNativeAnimals_2012.pdf [accessed 30 August 2019]

O'Loughlin LS, Green PT (2017) The secondary invasion of giant African land snail has little impact on litter or seedling dynamics in rainforest. Austral Ecology 42: 819-830. https://doi.org/10.1111/aec.12504

Pagad S, Genovesi P, Carnevali L, Schigel D, McGeoch MA (2018) Introducing the global register of introduced and invasive species. Scientific Data 5: 170202. https://doi.org/10.1038/ sdata.2017.202 
Pergl J, Pyšek P, Bacher S, Essl F, Genovesi P, Harrower CA, Hulme PE, Jeschke JE, Kenis M, Kühn I, Perglová I, Rabitsch W, Roques A, Roy DB, Roy HE, Vilà M, Winter M, Nentwig W (2017) Troubling travellers: are ecologically harmful alien species associated with particular introduction pathways?. Neobiota 32: 1-20. https://doi.org/10.3897/neobiota.32.10199

Pergl J, Sádlo J, Petrusek A, Laštůvka Z, Musil J, Perglová I, Šanda R, Šefrová H, Šíma J, Vohralík V, Pyšek P (2016) Black, Grey and Watch Lists of alien species in the Czech Republic based on environmental impacts and management strategy. Neobiota 28: 1-37. https://doi.org/10.3897/neobiota.28.4824

Prates I, Hernandez L, Samelo RR, Carnaval AC (2016) Molecular identification and geographic origin of an exotic anole lizard introduced to Brazil, with remarks on its natural history. South American Journal of Herpetology 11:220-227. https://doi.org/10.2994/SAJH-D-16-00042.1

Rockwell-Postel M, Laginhas BB, Bradley BA (2020) Supporting proactive management in the context of climate change: prioritizing range-shifting invasive plants based on impact. Biological Invasions 22: 2371-2383. https://doi.org/10.1007/s10530-020-02261-1

Roy HE, Bacher S, Essl F, Adriaens T, Aldridge DC, Bishop JDD, Blackburn TM, Branquart E, Brodie J, Carboneras C, Cottier-Cook EJ, Copp GH, Dean HJ, Eilenberg J, Gallardo B, Garcia M, Garcia-Berthou E, Genovesi P, Hulme PE, Kenis M, Kerckhof F, Kettunen M, Minchin D, Nentwig W, Nieto A, Pergl J, Pescott OL, Peyton JM, Preda C, Roques A, Rorke SL, Scalera R, Schindler S, Schonrogge K, Sewell J, Solarz W, Stewart AJA, Tricarico E, Vanderhoeven S, van der Velde G, Vila M, Wood CA, Zenetos A, Rabitsch W (2019) Developing a list of invasive alien species likely to threaten biodiversity and ecosystems in the European Union. Global Change Biology 25: 1032-1048. https://doi. org/10.1111/gcb.14527

Roy HE, Rabitsch W, Scalera R, Stewart A, Gallardo B, Genovesi P, Essl F, Adriaens T, Bacher S, Booy O, Branquart E, Brunel S, Copp GH, Dean H, D’hondt B, Josefsson M, Kenis M, Kettunen M, Linnamagi M, Lucy F, Martinou A, Moore N, Nentwig W, Nieto A, Pergl J, Peyton J, Roques A, Schindler S, Schönrogge K, Solarz W, Stebbing PD, Trichkova T, Vanderhoeven S, van Valkenburg J, Zenetos A (2018) Developing a framework of minimum standards for the risk assessment of alien species. Journal of Applied Ecology 55(2): 526-538. https://doi.org/10.1111/1365-2664.13025

Shine C, Williams N, Gündling L (2000) A guide to designing legal and institutional frameworks on alien invasive species. Gland, Switzerland: IUCN.

Simberloff D, Martin JL, Genovesi P, Maris V, Wardle DA, Aronson J, Courchamp F, Galil B, García-Berthou E, Pascal M, Pyšek P, Sousa R, Tabacchi E, Vila M (2013) Impacts of biological invasions: what's what and the way forward. Trends in Ecology \& Evolution 28(1): 58-66. https://doi.org/10.1016/j.tree.2012.07.013

Turbelin AJ, Malamud BD, Francis RA (2017) Mapping the global state of invasive alien species: patterns of invasion and policy responses. Global Ecology and Biogeography 26(1): 78-92. https://doi.org/10.1111/geb.12517

Van der Colff D, Kumschick S, Foden W, Wilson JRU (2020) Comparing the IUCN's EICAT and Red List to improve assessments of the impact of biological invasions. In: Wilson JR, Bacher S, Daehler CC, Groom QJ, Kumschick S, Lockwood JL, Robinson TB, Zengeya 
TA, Richardson DM (Eds) Frameworks used in Invasion Science. NeoBiota 62: 509-523. https://doi.org/10.3897/neobiota.62.52623

van Wilgen BW, Wilson JR (2018) The Status of Biological Invasions and Their Management in South Africa in 2017. South African National Biodiversity Institute, Kirstenbosch and DST-NRF Centre of Excellence for Invasion Biology, Stellenbosch, 398 pp.

Vilà M, Basnou C, Gollasch S, Josefsson M, Pergl J, Scalera R (2009) One hundred of the most invasive alien species in Europe. In: Drake JA (Ed.) Handbook of Alien Species in Europe, Springer, Dordrecht, 133-264. https://doi.org/10.1007/978-1-4020-8280-1_12

Vimercati G, Kumschick S, Probert AF, Volery L, Bacher S (2020) The importance of assessing positive and beneficial impacts of alien species. NeoBiota 62: 525-545. https://doi. org/10.3897/neobiota.62.52793

Visser V, Wilson JRU, Canavan K, Canavan S, Fish L, Maitre DL, Nänni I, Mashau C, O’Connor TG, Ivey P, Kumschick S, Richardson DM (2017) Grasses as invasive plants in South Africa revisited: patterns, pathways and management. Bothalia: African Biodiversity and Conservation 47: a2169. https://doi.org/10.4102/abc.v47i2.2169

Volery L, Blackburn TM, Bertolino S, Evans T, Genovesi P, Kumschick S, Roy HE, Smith KG, Bacher S (2020) Improving the Environmental Impact Classification for Alien Taxa (EICAT): a summary of revisions to the framework and guidelines. NeoBiota 62: 547-567. https://doi.org/10.3897/neobiota.62.52723

Wilson JRU, Datta A, Hirsch H, Keet J-H, Mbobo T, Nkuna KV, Nsikani MM, Pyšek P, Richardson DM, Zengeya TA, Kumschick S (2020) Is invasion science moving towards agreed standards? The influence of selected frameworks. NeoBiota 62: 569-589. https:// doi.org/10.3897/neobiota.62.53243

Wilson JRU, Faulkner KT, Rahlao SJ, Richardson DM, Zengeya TA, Van Wilgen BW (2018) Indicators for monitoring biological invasions at a national level. Journal of Applied Ecology 55(6): 2612-2620. https://doi.org/10.1111/1365-2664.13251

Zengeya TA, Ivey P, Woodford DJ, Weyl O, Novoa A, Shackleton R, Richardson DM, van Wilgen BW (2017) Managing conflict-generating invasive species in South Africa: Challenges and trade-offs. Bothalia: African Biodiversity \& Conservation 47(2): 1-11. https://doi.org/10.4102/abc.v47i2.2160 